\title{
Islamic Banking System and Mode of Leasing: A Comparative Analysis in the Light of Maqasid al-Shari'ah
}

\author{
Naseem Razi \\ International Islamic University, Islamabad, Pakistan
}

\begin{abstract}
This article discusses Islamic Banking System and its mode of leasing in the light of the objectives of Shari'ah. It explores that the objectives behind the introduction of Islamic finance and banking system were the elimination of capitalist banking interest, exploitation of poor segment of the society and the establishment of an economic system which may lead to sustain a balance economic order and social justice. In this context, it intends to analyze the mode of leasing provided by Islamic Banking system in the light of the objectives of Shari'ah and discloses that although Islamic Banking system is based on the principle of mudarbah, musharkah and Ijarah and deals with the customers in that context, yet apparently, the effects of these transactions are not much different from capitalist modes due to same consequences and effects of these transactions. It thus, provides a comparative analysis of the issue, i.e., mode of leasing at both Islamic and capitalist Banks. It argues that a common man can not avail Islamic financing/ leasing if he lacks financial resources. If a poor person tries to purchase something by way of ijarah through Islamic Banking finance, he does not find any difference in the payment of the total cost between capitalist mode of leasing and Islamic mode of ijarah. Hence, this article concludes that although Islamic financing achieved a remarkable development among the Muslims, yet there is a need to revise the policy and system of Islamic financing in the light of the objectives of Shari'ah. It also concludes that the mode of leasing provided at Islamic Banks does not accomplish the objectives of its establishment which is public interest. At present, this system is unable to assist the poor segment of the society or to provide ease to them.
\end{abstract}

Keywords: Islamic Banking System, mode of leasing, capitalist mode of leasing, comparison and compatibility with Maqasid al-Shari'ah

\section{Introduction}

The problem of relationship between the idealistic and realistic approaches of Islamic banking system has become a matter of debate among the contemporary Muslim scholars for many years. The problem stemmed from the notion that Islamic banking system and finance are based on the objectives of Shari'ah. It is a widespread phenomenon among the Muslims that Islamic banking system aims to operate in the light of the objectives of Shari'ah to eliminate capitalist banking interest, to eradicate exploitation of the poor segment of society and to maintain a balance economic order and social justice in the society. The Muslim jurists unanimously agreed that the objectives of Shari'ah are based on the general principles of the Qur'an and the Sunnah of the Prophet (pbuh),such as the principle of justice, equality, sympathy, equity, ihsan, removal of

Naseem Razi, P.hD, International Islamic University, Islamabad, Pakistan.

Correspondence concerning this article should be addressed to DR. Naseem Razi, House No.297,Street No.,154,G-11/1, Islamabad, Pakistan. E-mail: naseem.razi@iiu.edu.pk. 
hardship, public interest and that necessity makes a prohibited thing permissible etc (Ahmad Al-Ra' isuni, 1995, p.18).

The importance of the economic aspect of the life of the Muslims can be estimated by the fact that economic activities of the Muslims have been guided by Allah Almighty through 1400 verses of the Qur'an (Siddiqi, Muhammad Nijatullah, 1972, p.21). The Qur'anic verses like: (16:90)“

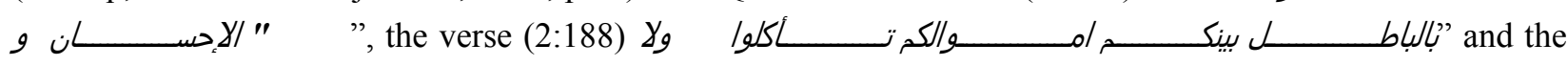

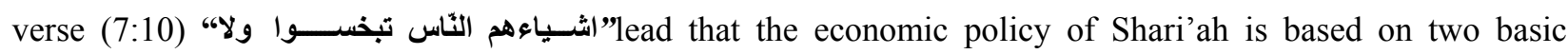
principles: Firstly is the prohibition of all types of exploitation though by way of riba, minimum ujrah, unfair dealing, cheating, fraud or by setting a trend of excessive profit and by neglecting the necessities of the people and secondly, on the recognition of the customary financing modes if not against its general principles of economics set out through revelation. It is thus, an irrefutable presumption that Qur'an in its totality focused on the public interest to provide ease to the people and to remove hardship from them (Al-Qurtabi, 1965, p.165).

It is this reason that the earlier Muslim jurists and the mufassirin have interpreted the verse "تبـســوا ومه ولاع "اشثـياءهم النّاس in the meaning of all types of exploitation, including unrestricted profit or participation in profit raising trend and in poverty (Al-Razi, 1967, p.145). All these lead that Allah Almighty created the whole universe for the benefit and interest of the people.

The term maqasid al-Shari'ah is plural of the word maqsad and used in the meaning of objective intended by the Law-giver behind every legal text (Al-Fasi, 'Abd al-Wahid, 1993, p.12). Technically, it has been defined as those ends which are prescribed by Allah Almighty to achieve for the benefits of the people to make the lives of the people easier and more comfortable (Yubi, Muhammad Sa 'd bin Ahmad, 1998, p.33).

Imam al-Shatibi (1966) described the objectives of Shari'ah in beautiful manners and divided them into three major categories, like daruriyyat (necessities), hajat (needs) and tehsinat (luxuries), with respect to their effects on the lives of the people. Daruriyyat means the basic and fundamental necessities of the people, without which, human life cannot be sustained. If they are not available, the life of the people may be destructed and fell into danger. These necessities are five in number and include protection of din, life, progeny, intellect and wealth. The daruriyyat is followed by hajat(needs) and tahsinat (luxuries). Hajat means to make the lives of the people easier by removing hardship from them and by providing ease to them, such as in case of some difficulty arising due to some external cause or reason and absence of which may cause law and order situation in the society.Tehsinatis the luxuries of the life and its scope is dependent upon the socio-economic conditions of the people in a society (Vol.1, pp.19-24). It thus, leads that the protection of fundamental necessities of life like religion din, life, progeny, intellect and wealth is a basic right of a Muslim. The protection of primary objectives of Shari'ah (din, life, progeny, intellect and wealth) demands that a Muslim must be provided proper food, clothing, shelter, medicine, knowledge of din and its obligations and prohibitions, worldly education, means of earning, family life, right to own property and transport as these are considered among the basic and fundamental necessities of each person and are the components of today's life. It is this reason that the four guided caliphs were so careful regarding the fulfillment of the necessities of the people on behalf of the state. It is reported that once Hadrat Umar issued an ordinance to provide a guideline to the governors of the state and ordered them to ensure the fulfillment of the necessities of the citizens (Shibli Nu'mani, 1985, p.267). During the era of four guided caliphs, the policies of the state treasury were based on the objectives of Shari'ah to provide ease to people and to remove hardship from them. Bayt al-maal was to be utilized for both types of economy, the macro which had to deal with the issues of national finance and growth 
of national economy as pointed out by S. M. Akhter (1970), that Macro-economic analyses the economy as a whole and studies national income, employment, consumption, investment, money supply, taxes, imports and exports etc,. It deals with the economic growth with stability (Vol.2, p.663). State treasury was also utilized to provide financial assistance to the individual consumers for trade and business to reduce poverty. In this way, the public treasury at that time was utilized for multiple purposes, for the fulfillment of the necessities of the people, like food, cloth and shelter, for preservation of social order, for growth of national economy, and for the protection against foreign attack and the government had very little expenditures.It is reported that Hadrat Umar adopted such far-reaching economic policies which resulted in the raising of public revenues and growth of the economy on one hand and, in the fulfillment of the basic needs of every citizen on the other. He declared that the fulfillment of the basic needs of the people is state responsibility (Nu'mani,pp.267-268). As Hugh Dalton (1967) described that individuals have needs, some of the needs can be most effectively satisfied through the agency of the state and by means of public expenditures (p.140).

The welfare policies of the state agencies led to motivate the companions to help the people and to benefit them. For instance, it is reported that the people used to leave their money with Hadrat Zubair bin Awwam (RA) in trust, but Hadrat Zubair bin Awwam was reluctant to hold the money as amanah (trust) due to fear that the money might be lost and it might be suspected that he was negligent in his security and established the principle of conversion of the trusted money into loan and thus, took the liability of risk just to facilitate the depositors. To create a financial cycling of the loaned money, he had to utilize the trusted/loaned money for trading and business. At the time of his death, he advised his son Abdullah bin Zubair by saying: "O! Son, dispose off my property to settle the loans" (Ibn Sa'ad, Vol. 2, p.81), and the loan amount was calculated at 2.2 million by his son. Thus, both state agencies and the rich segment of the society considered them under obligation to facilitate the needy and poor segment of the society at macro and micro levels which resulted in the prosperity of the Muslim state.

Although it is duty of a state to provide the necessities to its subjects, yet in absence of such a welfare state, the financing agencies and other institutions of economy are responsible to assist the people in achieving necessities, as it is a social responsibility as well.

The Qur'an states (70:24-25) “
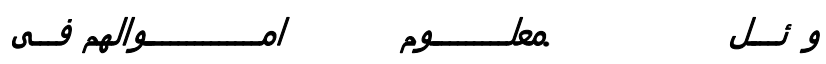

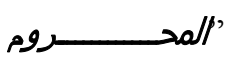

Economic growth can be achieved in many ways, but the objectives of Shari'ah do not acknowledge an economic growth, which allows corporate profits to rise almost without limit, while real wages are not permitted to increase appreciably and where no effort is made to regulate the excessively large profit margin. As Nawab Haider Naqwi (1967) stated that:

"The strategy of profit rise and similar policies lead to enhance the monopoly of domestic producers and create idle productive capacity in the industrial sector. The monopolistic producers do maximize their profits, curtail output and raise price. The common man on the other hand, suffered because he has to be forced to buy low-quality and high-priced good as a matter of patriotic duty. The social consumption does not maximize nor is social production raised to optimal level. Furthermore, such type of policy makes the accumulation of excess funds in the hands of the investors, which make them immune to it. It is, therefore, necessary to eliminate large profit margin and to discourage excessive reliance on the corporate sector" (p.57).

The ideal distribution from an economic point of view is that which causes a given amount of production to yield the maximum of economic welfare (Dalton, p.92). 
So far as concerned, the issue of economy of the contemporary Muslim states, unlike people's past, today, unfortunately, they lack welfare Muslim states and the people are helpless regarding their fundamental and basic needs. Hence, the burden shifts to the rich segment of the society and the financing agencies (Islamic banks) to care for the poor segment of the society. Dr. Mehmood Ahmad Ghazi (2010) pointed out that the objectives of Shari'ah focused on the normative aspects of economics which has a close relationship with ethical values and moral principles (p.16). In this context, Islamic banking system should be based on the principle of social liability and ethical values of Islam.

To reach at a conclusive point, this article first throws light on the objective behind the development of the modern banking system and then, it will compare the practicing mode of leasing/ijarah at both Islamic and conventional banks. At the end some conclusions will be drawn and some suggestions will be recommended to bring the contemporary mode of ijarah in accordance with objectives of Shari'ah.

\section{Development of Banking System}

The term "bank" has been derived from the Italian word "Banco", which means to compete with or to emulate (Thomas Dictionary of Banking, n.d.,p.45). Technically, banking system may be defined as a principal mechanism, through which, the money supply of the country is created and controlled.It operates with different types of financial institutions, such as commercial banks, saving banks, investment banks and the central banks of the state etc. Among the objectives of the banking system, the prevention of bank failure and the protection of the bank customers are against fraud and loss (Graham Bannock, R.E. Baxter.,\& Ray Rees. n.d., pp.36-39). The history of the modern banking system can be traced to medieval era during the $14^{\text {th }}$ century. Italy was the initiator of modern banking system, which was spread from northern Italy to Europe and London during $16-17^{\text {th }}$ centuries (Gilbart, J.W, 1922,Vol.1, p.9).

The end of the $19^{\text {th }}$ century dawned with development in the field of science and technology and in what was termed as industrial revolution (Baxter \& Ray, p.42).

A commercial bank can generate revenue in different ways, such as through interest, transaction fees and financial advices, etc. The principal mode of revenue is charging interest on the capital it lends out to customers. Bank profits from the difference between the level of interest it pays for deposits and other sources of funds, and the level of interest it charges in its lending activities. Deposits like current accounts, fixed deposits and saving accounts are primarily placed for the purpose of security and to earn profit by way of investment. The bank is held $100 \%$ responsible for these deposits in all circumstances, even in case of loss or damage to the bank (Akhtar, Vol.2, p.660). Banks also struggle to manage effectively their interest/profit rate spread in the face of low rates on loans, rate competition for deposits and the general market changes, industry trends and economic fluctuations, etc (Gilbart, p.123).

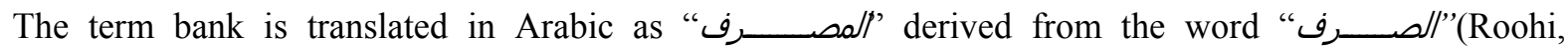

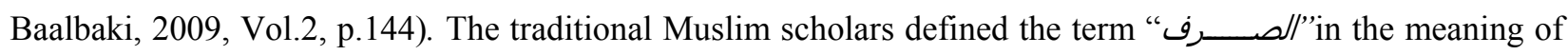

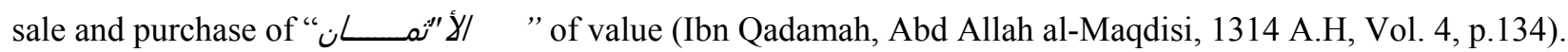
It is stated in Majallah al-Ahkam al-Adaliyyah (1977) that rent is hiring that is to say, the price paid for use of a thing; letting is giving on hire, and hiring is taking on hire.It is also defined in the meaning of sale/purchase of currency or money (Book, 2, p. 404). Islamic banking system refers to a system of banking that operates its economic activities in the light of the objectives of Shari'ah, the prime focus of which is public interest. It is also defined as a financial institution to promote Islamic financing (Khir, K, Gupta L.,\& Shanmugam, 
2008,p.12). Islamic banking system is a recent development introduced by the western bankers during the 1960s. The sole object behind the establishment of Islamic banking system was interest free economy and to provide the Muslims an alternative economic system free of all types of exploitation, as Omar (1996) pointed out that Islamic banking system operates ethical-based operation and activities with additional social function (p.21). The Islamic system of banking and economics is based on the presumption that whatever mode of financing an Islamic bank adopts, must not be against the objectives of Shari'ah and interest of the public. In modern communities, banks play a constructive role in promoting economic activities. They not only draw surplus money from the people and channel it towards productive purposes, but also are important creators of credit which enhances money supply in the economy (Akhter, Vol. 2, p.666). As Kenneth (1951) pointed out that money can be created or destroyed in the sense that the money is increased or decreased by the government or by the commercial banking system (p.28). The contemporary Islamic bank performs it functions as an agent/wakil of the customer, and like conventional bank, it charges agency fee (of same ratio) for the services which it provides such as on receiving of cash on behalf of the customer, inward bill of collection, and outward bill of collection, etc. Like conventional bank, it performs different functions, such as opening of bank account (bachat), remittance, zakat deduction, sale and purchase of foreign currency, sale and purchase of traveler's checks, etc. Among the Islamic modes of finance are, mushārkah, mudarbah, diminishing musharkah, murabahah, salam, istisna, istijrar, ijarah (leasing) and ijarah wa iqtina'etc (Abdel-Haq, p.47).

The industrial development, however, resulted in increased productive capacity and higher economic gains. The trickledown effect of the economic gains, however, was not even on the sociological side and resulted in an uneven distribution of wealth and increased economic poverty. This economic poverty further resulted in lack of opportunities as a privilege for human development, such as health, education, access to better employment opportunities and participation in decision making especially in political and development affairs and created a weaker group suffering from social isolation (Abdel-Haq, p.56).

\section{Mode of Leasing at Conventional and at Islamic Banks}

In modern banking system, leasing has become a household name and from cell phones to airplanes, everything is up for lease. In case of car leasing or home financing by way of leasing, the title of the commodity/property passes to the lessee at the end of the lease. In Islamic banking system, ijarah (0, $\longrightarrow$ /) facility is provided by way of rent or leasing of usufruct of a vehicle, office equipment, machinery and a house, etc. It is a contract based on profit, sharing between the bank and the client. The corpus of the leasing object, such as a car, a house or machinery remains in the owner ship of the bank, with respect to its share and only its usufruct is transferred to the client for an agreed period, at an agreed consideration (Imran Ashraf Usmani, p.130). In Islamic system of finance, the word lease is used in the meaning of 0 (ج) The Arabic term

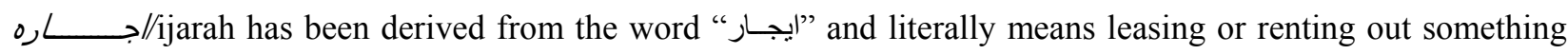
(Ibn Manzur, A.H., Vol.1, p.56). It is also used in the meaning of hiring of the services of a person on wage for his utilized services. In this case, the employer is called as musta'jir, while the employee is called ajir (Ibn Rushd, 1989, Vol.2,p.167).

Among the conditions of the lease, the subject of lease must have a valuable use, and if a thing had no usufruct at all, it cannot be leased. The period of lease must be determined in clear terms. The lessee cannot use the leased asset for any purpose other than the purpose specified in the lease agreement. If no such purpose is specified in the agreement, the lessee can use it for whatever purpose it is used in the normal course. The rent 
are must be determined at the time of the contract for the whole period of lease; that different amount of rent can be fixed for different phases during the lease period but should be agreed upon at the time of the lease contract (Ibn Rushd, Vol.2,p.168). If people do compare between lease at conventional banks and Ijarah at Islamic banks, they find some differences between the two like:

Table 1

Differences Between Leaseand Ijarah

\begin{tabular}{lll}
\hline S.NO & LEASE AT CONVENTIONAL BANKS & IJARAH AT ISLAMIC BANKS \\
$\underline{1}$ & Difference in terminologies such as lease, lessor and lessee & Ijarah, Aajir and ajir \\
$\underline{2}$ & Rent starts from the day of the agreement & When the asset is handed over to the client \\
$\underline{3}$ & Money is considered as commodity & Not so \\
$\underline{4}$ & Profit is against money invested in the property & $\begin{array}{l}\text { Profit is the rent of respected share of the bank in the } \\
\text { property }\end{array}$ \\
$\underline{5}$ & The leased asset is ensured through insurance companies & The leased asset is ensured through takaful \\
$\underline{6}$ & The bank charge penalty for late payment & To pay certain amount to charity \\
\hline
\end{tabular}

This table shows that, lease at Islamic banks is different from the lease at conventional banks, such as in conventional banking, money is considered as commodity, while in Islamic, the usufruct of the property is subject to be rented out. In Islamic takaful, insurance rate is charged when the car is delivered not when it is ordered by the bank as happened in conventional mode of leasing. Similarly, in Islamic leasing, rent can be fixed for different phases during the lease period. These differences however, disappear when people discuss similarities and consequences of both systems by way of practical implication of lease and Ijarah. A

Table 2

Similarities Between Leaseand Ijarah

\begin{tabular}{|c|c|c|}
\hline S. No. & LEASE AT CONVENTIONAL BANKS & IJARAH AT ISLAMIC BANKS \\
\hline 1 & An agreement between bank and client & Same \\
\hline$\underline{2}$ & Bank retains the ownership of the leased property during the period of contract & Same \\
\hline$\underline{3}$ & Right and liabilities of ownership w.r.t share & Same \\
\hline$\underline{4}$ & Rights and liabilities of usufruct lie within the client & Same \\
\hline$\underline{5}$ & Money is considered as medium of exchange and store of value & Same \\
\hline \multirow[t]{2}{*}{$\underline{6}$} & Financing for tangible assets & Same \\
\hline & Time value is the basis for interest & Same: time value is the basis for profit \\
\hline$\underline{7}$ & Bank charges for the services which it provides & Same \\
\hline$\underline{8}$ & Mark up rate fluctuates in the light of the duration of years in agreement & $\begin{array}{l}\text { Variation of profit ratio in the light of } \\
\text { the duration of years }\end{array}$ \\
\hline
\end{tabular}

Table 2, thus, reveals that practically however, like conventional banking system, in Islamic banking system, the money is considered as medium of exchange and of value. In both systems, time value is the basis for profit/interest. The rate of insurance is also same. In this way, there is hardly any difference between the two in the effects and consequences of the lease contract. The difference is in terms of terminology and organization. For instance, in conventional banks, the mark up rate is the most important and fluctuates in the light of the duration of years in agreement and stays on the ratio of $20 \%$ more often and the same happened in Islamic banks in the name of rent. In conventional bank element of loss is absent while in Islamic banking theoretically, profit ratio is fluctuates, yet no real loss is occurred.

To elaborate the practical situation of the objectives of Shari'ah at Islamic banks, a case study of home 
financing by way of diminishing Musharkah/leasing through Meezan Islamic Bank, Pakistan which is the first Islamic bank in Pakistan working since 1995, will be presented to make it clear that although Islamic financing achieved a remarkable development among the Muslims, yet practically, it is working like conventional banks to compete the market trend at higher profit margin, to earn more and more with the argument that Shari'ah allows the use of any market factor as benchmark to determine the profit rate of a particular product, but seems indifferent of the socio-economic conditions of the Muslims.

\section{A Practical Review of Home Financing at Meezan Islamic Bank}

The economic facts reveal that prosperity of a nation in fact, lies in its savings (Thomas, J. Donaldson.,\& R. Edward Freeman, 1995, p. 12). But in Pakistan, the proportion of savings is very low due to low income or salaries on the one hand, and abnormal increase in daily life expenditures on the other. Out of every hundred rupees of people's national income, 85 rupees are consumed and only 15 rupees are saved, which means that the amount which is available to invest for economic growth and development is too inadequate in relation to the country's needs. Domestic savings in Pakistan was about 8.7\% of GDP in 2012-13, while desired saving rate is $25 \%$ (Ishrat Hussain, 2010,p.12). Another bitter reality is that in Pakistan, the average monthly income of the employed sector is only Rs.16254 per head and the people have been spending more on the rent and housing. For instance, the spending on housing was 25\% during 2013 (Ayaz Ahmed.,\& Henna Ahsan, (PIDE), 2011,p.6). In Pakistan, the richest households have comparatively smaller family size than the middle class income and poor households The most horrible fact is that more than $50 \%$ of Pakistani population is living below the poverty line (USD1.5 per day). In Pakistan, services sector has emerged as the main driver of economic growth and plays a vital role in sustaining economic activities. In case of Pakistan, the shares of services are increasing in all sectors of economy over the period. In fact, the growth rate of services sector is higher than the growth rate of agriculture and industrial sector. Services sector accounts for $57 \%$ of GDP during 2012-13 (Report, Economic Survey of Pakistan (2012-13), p.iv). The share of the services sector has reached to $58.1 \%$ in 2013-14. Services sector contains six sub-sectors including: transport, storage and communication; wholesale and retail trade; finance and insurance; housing services (ownership of dwellings); general government services (public administration and defense); and other private services (social services).

In Pakistan, both conventional and Islamic banks offer home financing and claim to be accommodative by way of mutual agreement, which is considered a bilateral agreement where the bank buys a commodity, e.g., the house from a selected dealer and leases it to the client at an agreed (practically on the terms and conditions of the bank) monthly rent and period. Keeping aside the poor segment of the society (more than 50\%), the middle class community and salaried persons mostly seek for car leasing or house financing.

The following table shows the detail of term and conditions which the applicant must fulfill before applying for home leasing both at Islamic and conventional banks, such as:

Table 3

\begin{tabular}{llll}
\hline No & Terms and Conditions for Car Leasing & Conventional Bank & Meezan Islamic Bank \\
\hline 1 & Pakistani nationality & Same & Same \\
2 & Account holder of that particular bank & Same & Same \\
3 & Salaried, business men or self-employed & Same & Same \\
4 & 20 to 60 years of age if salaried person & Same & Same \\
5 & 20 to 64 years of age if a business man & Same & Same \\
\hline
\end{tabular}


(Table 3 continued)

\begin{tabular}{llll}
\hline No & Terms and Conditions for Car Leasing & Conventional Bank & Meezan Islamic Bank \\
\hline 6 & Copy of CNIC\& photographs & Same & Same \\
7 & Latest original salary slips and bank statement of last 3 months & Same & Same \\
8 & Proof of business \& Bank statement of last 6 months & Same & Same \\
9 & Insurance & Compulsory & Optional \\
\cline { 2 - 2 } & To keep an amount equal to first three installments as lien in his & & Compulsory \\
\hline
\end{tabular}

On the basis of above mentioned conditions, the Meezan Islamic Bank offers easy home financing based on the principle of Diminishing Musharakah and ijarah (leasing), but if he has no saving, he cannot inter into lease agreement. The nature of the contract is co-ownership in a house. Meezan bank shares in the cost of the house being purchased. The bank first creates joint ownership of a purchased house and divides it into units with respect to the share of the bank as per tenure on the basis of total period of leasing, and then gradually transfers ownership through sale of units of its share to the customers. The profit charged by the bank is declared as rent for the use of its share of the house during the contracting period on the basis of ijarah. The profit rate is $13.45 \%$, which is floating rate based on average of 12-month KIBOR (Karachi Interbank Offer Rate). The rentals are fixed for every 12 month period. The profit margin is directly linked to market trends to determine the profit rate of a product.The rent will keep on decreasing as customer's ownership in the house increases and that of the Bank decreases.

For an effective result, a case study is of Home Financing process and its effects on a civil servant/government officer of 19 scale, residing at the middle class sector 1-10, Islamabad where $70 \%$ people are salaried and living on hiring, but has no house and wants to enter into a lease agreement with Meezan Islamic bank to purchase a home of $1000 \mathrm{sq}$ feet in 1-10 sector (worth Rs.10 million). The particulars of the client Mr. $\mathrm{X}$ are as:

Job of Mr. X

Age

Disposable Income

$$
\text { : } \quad \text { Government Employee (19 scale) }
$$

: 45 years old

: $\quad$ Rs $100000 \mathrm{p} / \mathrm{m}$ (the highest salary package)

Minimum utility expenditure : Rs 80000 p/m (wife and three children)

Others: Rs. 10000

Savings : Rs. $10000 \mathrm{p} / \mathrm{m}$

Suppose that Mr. X now goes to Meezan Islamic bank with a saved amount of Rs. 2500,000 with a hope of purchasing a house by way of diminishing musharkah/ijarah. In the light of a set formula that is a gap between the age of the client and his superannuation age $=60-45=(15 \mathrm{yrs})$, the bank offers him only Rs. 2500000. The rest of $75 \%$ amount must be provided by the applicant which he could not provided and thus, the client who was a respectable member of the society and a contributor in the economic growth of the country could not succeed to purchase a small house to provide basic need of shelter to his family and return back hopeless and disappointed.

Now suppose that Mr. X provides an amount of Rs. Six million or $60 \%$ of the said house. The particulars of the contract will be:

House evaluated cost : Rs. $10 \mathrm{M}$

Customer's share : Rs. 6 M (60\%) 
Tenure of transaction year : $(60-45=(15 \mathrm{yrs})=15$ year

Bank's Share : Rs. 4 M (40\%)

House divided into units : $15 \mathrm{yrs} \times 12 \mathrm{month}=180$ units

Cost per unit : Rs. 22222.22

Total cost of 180 units : Rs.4M

Rent for 1st month/180 U: Rs. 44733

Internal rate of return $\quad: 13.47 \%$

Total paid by customer in $1^{\text {st }} \mathrm{m}:$ Rs. 67949

Additional amount paid in the name of rent $/ 15$ years: Rs. $3.6 \mathrm{M}$

Total paid by the client during 15 years: $4 \mathrm{M}+3.6 \mathrm{M}=7.6 \mathrm{M}$

If people draw proportionate share and rent analysis of both parties, they come to know that:

Table 4

\begin{tabular}{llll}
\hline Investment & Bank & Customer & Total \\
\hline Share in amount & Rs.4M & Rs.6M & Rs.10M \\
Proportion & 2 & 3 & 5 \\
Property into Units & $180 \mathrm{U}$ & $270 \mathrm{U}$ & 450 \\
Rent /Ist month & Rs. 44733 & Rs.67100 & Rs. 111833 \\
\hline
\end{tabular}

This table shows the proportionate rent analysis of both parties. Suppose that the whole house is divides into units with respect to the proportion of the shares of both parties, it reveals that bank share is divided into $180 \mathrm{U}$ and the client's share into $270 \mathrm{U}$. The total units will be $450 \mathrm{U}$

In the light of above mentioned formula, the bank charges Rs. 44733/180 U, while the client may charge Rs.67100/270 U. Thus, the rent for first month of the whole house/450 units will be Rs.111833, while the said house is currently available at the rent of Rs.30000 per month.

According to this current market trend and rent practice, the rent which may be charged by the bank/180 units should be Rs.12000, and if people add annual increase of $10 \%$ in the rent of the said house with respect to bank share, it would be Rs.13200 next year. Further, the prescribed rent (Rs. 44733/180 units) decreases very slowly like after three months payment of Rs.134199 and after purchase of three units of the house from the bank, only few hundred (Rs.745) will be decreased and the rent will be Rs.43988 against 176 units. Thus in the light of socio-economic conditions of Pakistani society, one can easily understand that majority of the employed persons cannot even think about seeking any financial assistance from Islamic banks to accomplish necessities of life, such as a car or a home due to severe conditions. For instance, an important condition is that the client is required to provide at least $50-60 \%$ of the leasing object. Further, it is also necessary that he should have an amount equal to the first three installments as lien in his bank account before disbursement of Ijarah. Likewise, profit rate is very high and like conventional mode of mark up fluctuates in the light of the duration of agreement.

\section{Conclusion}

This research thus concludes that ijarah at Islamic banks is being conducted on the basis of higher profit rate, greater than market trend and is contributing in the raising of maximum profit margin. It seems that Islamic bank could not achieve its target which was elimination of exploitation of poor segment of the society and establishment of a balanced economic order and social justice. It is also concluded that the policies of 
Islamic financing are made by ignoring the socio-economic issues of the poor Muslims and to resolve them to accomplish the objectives of Shari'ah. At present, lease transaction whether it is executed through conventional bank or Islamic bank, the client bears the same costs and consequences and does not feel any difference in total cost. For instance, in above mentioned case, the client has to pay Rs.3.6M in the name of rent, which is not only equal to the amount of interest at conventional bank, but also greater than current market trend and resulted almost in doubling of the invested amount by the bank (Rs.4M). This simply can be declared as " أضــافا " مضــاعفة by a common man who concerns only with his financial means and basic necessities of life. Lastly, it is concluded that the current modes of Islamic financing and leasing are unable to assist the poor/middle class of the society to provide ease to them and only rich can avail the Ijarah facility to have a car or a home. It is this reason that majority of the common men do not appreciate rather believe that Islamic banking system is a competitor of the conventional banking system and just a gimmick and a change of nomenclature of the terms. In the light of above mentioned conclusions, this research recommends that contemporary system of Islamic banking should be clearly defined to spell out its policies in the light of objective of Shari'ah. Islamic Banking system needs institutional changes in terms of accountability not to be just profit-making private enterprise. It should provide a package of policy reform through soft profit, so, it may emerge as a key sector for growth of the economy and reduction of the poverty. There is also a pressing need to find out new avenues of Islamic financing like qard hashanah in the banking system to assist the lower/middle class of the society. Steps should be taken to eliminate evils of exploitation, such as highly distorted distribution of wealth, feudalism, minimum ujrah and a trend of higher profit margin, etc. Such economic policies should be introduced, which may cause a given amount of production to yield the maximum of economic welfare. It is also suggested that Islamic banks should develop a system of minimum profit margin/rent in the light of objectives of Shari'ah lower than market trend to enable the poor and middle class people to fulfill their dream of having their own vehicle and home as both are basic needs of human beings. In a state like Pakistan, where almost $50 \%$ of the population are living below the poverty line, unreasonable/higher profit or rent, which results in the exploitation of the poor lessee is prohibited in Islam. The profit, fee and fare/rent should be determined in the light of the socio-economic conditions of the people in a society. The mere argument that profit, fee and fare is lawful and a lessor/seller can sale his object on the profit what he thinks appropriate does not meet the objectives of Shari'ah.

Lastly, it is suggested that Islamic banks should offer vehicle leasing and home financing by way of qardhasanah to the poor segment of the society. For middle class people, it should provide home financing by way of minimum rent in the light of the monthly income and expenditures of the applicant to take back original cost of the vehicle/home, and at minimum profit/rent at the time when the agreement is made and sale is done not with so-called rent or profit determined in the light of the duration of the contract, which is in fact conventional mode of mark up.

This policy will also discourage the current market trend of unrestricted profit rise particularly, in a society where real wages are not permitted to increase appreciably and where no effort is made to regulate the excessively large profit margin. Islamic banks should not ignore the fact that home building is among the

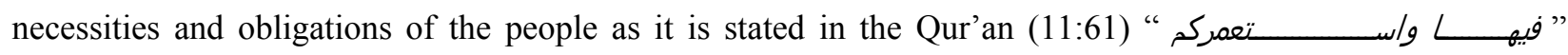
which means that Allah Almighty demands construction on earth and is an obligation and who he does it or assists, in fact, performs its obligation ( Al-Qurtabi, Vol. 8, p.228). It thus, leads that Islamic financing agencies/banks are under obligation to assist the people to construct on earth and to have their own homes. 


\section{References}

Abd Allah al-Maqdisi, Ibn Qadamah. (1314 A.H.). Al-Mughni.. ( p. 134). Cairo: Al-Matba'ah al-Amiriyyah. Abu Abd Allah Muhammd bin Umar,Al-Razi. (1967). Al-Tafsir al-Kabir. (p. 145). Beirut: Dar Ihya al-Turath al-'Arabi. Abu Ishaq Ibrahim bin Musa, Al-Shatibi. (1966). Al-Muwafaqat fi Usul al-Ahkam. ( pp. 19-24). Misr: Matba 'Salfiyyah. Ahmad bin 'Ali al-Razi, Abu Bakr, Al-Jassas. (1357 A.H.). Ahkam al-Qur 'an. (p. 233). Egypt: Matba'h al-Bahi 'h al-Misriyyah. Allal Al-Fasi, 'Abd al-Wahid 'Abd al-Salam. (1997). Maqasid al-Shari 'ah al-Islamiyyah wa Makarimiha. (p. 7).Beirut: Dar al-Gharb al- Islami.

Allamah Shibli Nu'mani. (1985). Al-Farooq. (p. 267). Lahore: Maktabah Rahmaniyah.

Al-Omar, F., \& Abdel-Haq, M. (1996). Islamic Banking: Theory, Practice and Challenges. (p. 21). Karachi: Oxford University Press. Al-Qurtabi. (1965). Al-Jami li Ahkam al-Qur'an.. (p. 165). Beirut: Dar Ihya al-Turath.

Ayaz Ahmed., \& Henna Ahsan. (2011). Contribution of Services Sector in the Economy of Pakistan: A Report prepared by Pakistan Institute of Development Economics (PIDE), Islamabad.

Ahmad, al-Ra' isuni. (1995). Nazriyyah al-Maqasid 'inda al-Shatibi. (p. 18). N.p: Ma'had al-'Ilmi li al-Fikr al-Islami.

Bannock, Baxter., \& Ray. (1967). The Penguin Dictionary of Economics. (p. 270). UK: Penguin Reference.

Gilbart, J.W. (1922). The History, Principles and Practice of Banking. ( p. 9). London: G. Bell \&Sons, Ltd.

Graham Bannock, R.E. Baxter., \& Ray Rees. The Penguin Dictionary of Economics, 36.

Hugh Dalton. (1980). Principles of Public Finance. (p. 140). London: Routledge \& Kegan Paul LTD.

Ibn Sa'ad. (1985). Tabaqat al-Kubra. (p. 109). Beirut: Dar Beirut Li al-Taba'ah wa al-Nashr.

Isma 'il, Ibn Kathir. (1980). Tafsir al-Qur'an al- 'Ažim ( p. 78). N.P: Cairo: Dar al-Ma'arif.

Ishrat Hussain. (2010). Paper presented at the Seminar on "Pakistan China Relation in the 21st Century". (p. 12). Beijing.

Kenneth K. Kuriharah. (1951). Monitory Theory and Public Policy. (p. 28). London: Unwin University Book.

Khir, K., L.Gupta., \& B. Shanmugam. (2008). Islamic Banking: A Practical Perspective. (p. 12). Malaysia: Pearson Malaysia Sdn. Bhd. Selangor.

Mehmood Ahmad Ghazi. (2010). Mahadirat Ma'ishat wa Tajarat. (p. 16).Lahore: Al-Fasail Nashiran wa Tajiran Kutub.

Muhammad Imarn Ashraf Usmani. (n.d.). Meezan Bank's Guide to Islamic Banking (pp. 138-39). Zeenat Zubairi. (Ed.), Karachi: Dar al-Isha'at.

Muhammad Sa'd bin Ahmad, al- Yubi. (1998). Maqasid al-Shari ah al-Islamiyyah 'Ila qati uha bil 'Adillah. (p. 33). Riyadh: Dar al-Hijrah li al-Nashr wa al-Tawzi.

Majallah al-Ahkam al-Adaliyyah. (1969). Book, 2, article, 404. Karachi.

Muhammad bin AbdAllah al-Undalasi., \& Ibn Al-Arabi. (2012). Ahkam al-Qur'an. (p. 319). Beirut: Dar al-Kutub al-Ilmiyah.

Muhammad bin Ahmad,Ibn Rushd. (1989). Bidayah al-Mujtahid wa Nihayah al-Muqtasid. (p. 167). Lahore: Faran Academy.

Muhammad bin Jarir bin Yazid bin Kathir, Al-Tabari. (1992). Jami 'al-Bayan 'an Ta 'wil al-Qur 'an. (p. 554). Beirut:Dar al-Kutub al-'Ilmiyah.

Muhammad bin Mukarram, Ibn Manzur. (1345 A.H.). Lisan al-Arab. (p. 56). Beirut: Tab'a Dar Sadir.

Muhammad Nijatullah, Siddiqi. (1972). The Economic Enterprise in Islam. (p. 21). Lahore: Islamic Publications.

Report, Economic Survey of Pakistan. (2012-13). Presented by Mr. Ishaq Dar, the Finance Minister to the government of Pakistan. (p. iv). Islamabad.

Report, HOUSEHOLD INTEGRATED ECONOMIC SURVEY. (September-2011). Government of Pakistan, Statistics Division Federal Bureau of Statistics. (p. 5-7). Islamabad. Retrieved from www.pbs.gov.pk

Rohi BaalBaki (2010). Al-Mawrid. (p. 37). Beirut: Dar al-Ilm Lil Malayin.

S.M. Akhtar (1970). An Introduction to Modern Economics.(p. 663). Lahore: Publishers United Ltd.

Syed Nawab Haider Naqvi. (1981). Ethics and Economics: An Islamic Synthesis. (p. 55). London: The Islamic Foundation. Tahir, Ibn 'Ashur. (1988). Maqasid al-Shari ah al-Islamiyyah. (p. 58). Muhammad Tahir. N.p: Dar al-Basar li al-Intaj al-'Ilmi. Thomas Dictionary of Banking $11^{\text {th }}$ ed. (p. 45). London: The New Era Publishing Co. Ltd.

Thomas, J. Donaldson., \& R. Edward Freeman. (1955). Business as Humanity. (p. 12). New York: Oxford University Press. 